\title{
Catalytic Hydrogenation of Furfural Diethyl Acetal to Ethyl Furfuryl Ether
}

\author{
Valery E. Tarabanko*a, Irina L. Simakova ${ }^{\mathrm{b}}$, \\ Marina A. Smirnova a and Konstantin L. Kaygorodova \\ anstitute of Chemistry and Chemical Technology SB RAS \\ FRC KSC SB RAS \\ Krasnoyarsk, Russian Federation \\ ${ }^{b} F R C$ Boreskov Institute of Catalysis SB RAS \\ Novosibirsk, Russian Federation
}

Received 30.05.2021, received in revised form 10.08.2021, accepted 01.09.2021

\begin{abstract}
The process of catalytic hydrogenation of furfural diethyl acetal to ethyl furfuryl ether on the different catalysts (palladium, palladium-rhenium and copper-ruthenium on Sibunit in reduced forms) was studied. It was found that hydrogenation of the furan ring with the formation of THF diethyl acetal occurs on all the catalysts. Ethyl furfuryl ether becomes the main product while carrying on the second hydrogenation cycle on spent palladium catalyst (yield and selectivity up to $55 \%$ and $85 \%$, respectively).
\end{abstract}

Keywords: Ethyl furfuryl ether, furfural, furfural diethyl acetal, catalytic hydrogenation, palladium catalysts.

Citation: Tarabanko, V.E., Simakova, I.L., Smirnova, M.A., Kaygorodov, K. L. Catalytic hydrogenation of furfural diethyl acetal to ethyl furfuryl ether, J. Sib. Fed. Univ. Chem., 2021, 14(3), 281-289. DOI: 10.17516/1998-2836-0237

(C) Siberian Federal University. All rights reserved

This work is licensed under a Creative Commons Attribution-NonCommercial 4.0 International License (CC BY-NC 4.0).

* Corresponding author E-mail address: veta@icct.ru 


\title{
Каталитическое гидрирование диэтилацеталя фурфурола в этилфурфуриловый эфир
}

\author{
В. Е. Тарабанько ${ }^{a}$, И. Л. Симакова \\ М.А. Смирнова ${ }^{\text {a }}$ К.Л. Кайгородов ${ }^{a}$ \\ ${ }^{a}$ Институт химии и химической технологии СО РАН \\ ФИЦ КНЦ СО РАН \\ Российская Федераиия, Красноярск \\ ${ }^{6}$ Институт катализа СО РАН \\ Российская Федерачия, Новосибирск
}

\begin{abstract}
Аннотация. Изучен процесс каталитического гидрирования диэтилацеталя фурфурола в этилфурфуриловый эфир на различных катализаторах (палладий, палладий-рений и медь-рутений на Сибуните в восстановленных формах). Установлено, что на всех катализаторах протекает процесс гидрирования фуранового кольца с образованием диэтилацеталя ТГФ. Показано, что основным продуктом второго цикла гидрогенизации на отработанном палладиевом катализаторе становится этилфурфуриловый эфир (выход и селективность до 55 и 85 \% соответственно).
\end{abstract}

Ключевые слова: этилфурфуриловый эфир, диэтилацеталь фурфурола, каталитическое гидрирование, палладиевые катализаторы.

Цитирование: Тарабанько, В.Е. Каталитическое гидрирование диэтилацеталя фурфурола в этилфурфуриловый эфир / В.Е. Тарабанько, И. Л. Симакова, М. А. Смирнова, К. Л. Кайгородов // Журн. Сиб. федер. ун-та. Химия, 2021, 14(3). C. 281-289. DOI: 10.17516/1998-2836-0237

\section{Introduction}

The processing of renewable plant materials into biofuels is an intensively developing field of chemical and biotechnological research, the basis of future chemical technologies. Products of this type are obtained either by biochemical methods (ethanol, butanol, etc.), or by chemical methods (products of pyrolysis, hydrolysis, etc.). Acid-catalyzed conversion of hexose carbohydrates are characterized by relatively high rates compared to enzymatic and limited product assortment(mainly 5-hydroxymethylfurfural, 5-HMF and levulinic (4-ketopentanoic) acid (LA) and their ethers and esters [1,2]. A limited product assortment distinguishes hydrolysis processes from pyrolitic technologies. Promising additives to gasoline $(2,5$-di-methylfuran, DMF, research octane number $(\mathrm{RON})=119)[3,4]$ and diesel fuels (butyllevulinate, butylvaleroate) are obtained by catalytic hydrogenation of these products and their esters.

Methods for synthesis of biofuels based on furfural (FAL), an available product of pentose acidcatalyzed conversion, are being developed in Russia and abroad [3,6-8]. It should be noted that agricultural waste from herb plants, from which the FAL production is most effective, can be cheaper than wood waste, from which 5-HMF can be obtained [5]. One of the most promising products of furfural hydrogenation, 2-methylfuran (MF, RON $=131)$, passed road tests $(90,000 \mathrm{~km})$ in a mixture with gasoline successfully [3]. Furfuryl alcohol (FA) has a high RON $=134$ [6]. 
The possibility of synthesis of 2-ethoxymethylfuran (ethyl furfuryl ether, EFE) with a yield of $30-50 \%$ by direct FA alkylation over zeolite and sulfuric acid catalysts was shown and its octane number $(\mathrm{RON}=110)$ was determined [7]. The octane numbers of butyl furfuryl and propyl furfuryl ethers were estimated (98 and 113, respectively) [9, 10]. It should be noted one advantage of alkyl furfuryl ethers in comparison with methyl furans - a half of the stoichiometric hydrogen consumption while they are obtained from FAL. Traditional methods of obtaining alkyl furfuryl ethers, however, are extremely expensive and complicated [11, 12], or low selective: the FA acid-catalyzed alkylation by the ethanol gives $30 \%-50 \%$ product yield [7]. It can be explained by the side acid- catalyzed processes of FA resinification and its conversion to levulinic acid. These specific limitations of the FA alkylation require the search for other methods for the preparation of alkyl furfuryl ethers. Recently ethyl furfuryl ether was obtained by direct alkylation of FA by the ethanol on a zirconium-modified SBA-15 catalyst with a yield up to $87 \%$ [13].

More promising process for the production of alkyl furfuryl ethers is the hydrogenation of FAL (or 5-HMF) in alcoholic media [14-17]. Propylfurfuryl ether with a yield of 10-19\% was obtained by FAL hydrogenation in propanol on copper-ruthenium and platinum catalysts. It has been shown that propylfurfuryl ether under these conditions is formed mainly not from FAL, but from its acetal [10]. It has been shown that 5-HMF hydrogenation in propyl alcohol on a $\mathrm{Pd} / \mathrm{C}$ catalyst gives 5-hydroxymethyl-2-propyloxymethylfuran with a selectivity of more than $80 \%$ [14]. Furfural in 2-butanol on a tin-containing zeolite is hydrogenated to form 2-(2'-butyl-oxymethyl)furan (58 \% selectivity and $86 \%$ FAL conversion) [15]. EFE was obtained by FAL hydrogenation in ethanol on a $\mathrm{Pd} / \mathrm{C}$ catalyst with $83 \%$ selectivity and $98 \%$ FAL conversion [16]. Propyl and butyl furfuryl ethers were obtained on a $\mathrm{CuRu} / \mathrm{C}$ catalyst with selectivity of 62 and $41 \%$, respectively [17].

The papers [10, 14-17] assume that the formation of alkyl furfuryl ethers proceeds through the stages of formation and hydrogenolysis of acetals of furfural or 5-HMF. Consequently, the hydrogenolysis of FAL acetals into the corresponding ethers may gives alkyl furfuryl esters with better yields and selectivity (Fig. 1) compared to the processes of hydrogenation of FAL alcoholic solution.

The acetal hydrogenation to ethers is rarely considered in the literature for two reasons. First, the acetal group is quiet inert and is used to protect the carbonyl group in the hydrogenation of other molecule parts. Second, in most cases except furfuryl alcohol, ethers are easily synthesized by direct alkylation. It is known that 5-chloromethylfurfural acetal is easily hydrogenated into DMF on $\mathrm{Pd} / \mathrm{C}$ catalyst [18].Hydrogenation of 5-butoxymethylfurfural in butanol is accompanied by the formation of an acetal, and 2,5-dibutoxymethylfurfuran and 2,5-dibutoxymethyltetrahydrofuran, products of the hydrogenolysis of 5-butoxymethylfurfural dibutylacetalwere registered as the products of the process $[19,20]$.

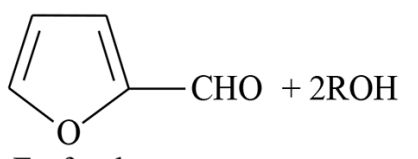

Furfural

(FAL)

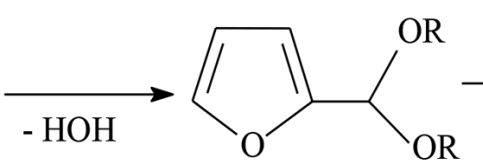

Furfuryl dialkyl acetal

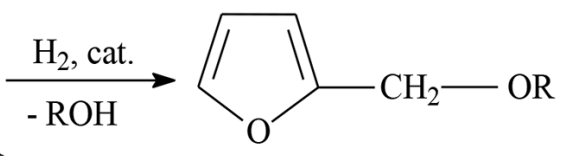

Alkyl furfuryl ether

Fig. 1. Scheme of alkyl furfuryl ether synthesis

$$
-283-
$$


The goal of this work is to study the possibilities of EFE synthesis by catalytic hydrogenation of furfural diethyl acetal (2-(diethoxymetyl)furan, FDEA).

\section{Experimental part}

Starting materials and reagents. FAL (98\% of the basic substance, Acros Organics) was used without additional purification. Technical calcium oxide was calcined; ethanol was distilled over calcium oxide at atmospheric pressure. FDEA was obtained by direct interaction of FAL with ethanol [21]. To shift the equilibrium, a solution of furfural in ethanol $(1: 3 \mathrm{~mol} / \mathrm{mol})$ was kept at room temperature for 30-60 days in a desiccator with calcium oxide at the bottom as a dehydrating agent. The obtained FDEA was washed by water to remove unreacted furfural and ethanol. The organic phase was dried with calcined potassium carbonate and distillated at $18-20$ torr and b. p. $83-85^{\circ} \mathrm{C}$.

Synthesis of hydrogenation catalysts. The catalysts were prepared by the deposition of active components on a mesoporous Sibunit $\left(\mathrm{SSA}=355 \mathrm{~m}^{2} / \mathrm{g}\right)[22]$ and $\mathrm{TiO}_{2}\left(\mathrm{SSA}=110 \mathrm{~m}^{2} / \mathrm{g}\right)$ fraction $40-70 \mathrm{mkm}$. The $6 \% \mathrm{Pd} / \mathrm{C}$ catalyst was synthesized by impregnating the Sibunit by $\mathrm{PdCl}_{2}$ solution followed by reduction to metallic palladium in a hydrogen stream when heated to $250{ }^{\circ} \mathrm{C}$ with a heating rate of $1.5^{\circ} \mathrm{C} / \mathrm{min}$ [23]. The $2 \% \mathrm{Pd} / \mathrm{TiO}_{2}$ catalyst was prepared by incipient wetness impregnation. This catalyst was reduced in a temperature programmed regime till $400{ }^{\circ} \mathrm{C}$ (temperature ramp $2{ }^{\circ} \mathrm{C} / \mathrm{min}$ ) [24].

The synthesis of a bimetallic catalyst $8 \% \mathrm{CuRu}$ (atomic ratio of metals copper/ruthenium $=3: 1$ ) was carried out by the joint impregnation of $0.2 \mathrm{M} \mathrm{RuCl}_{3}$ and $0.5 \mathrm{M} \mathrm{Cu}\left(\mathrm{NO}_{3}\right)_{2}$ aqueous solutions by according to the moisture capacity of the carbon support. The dried catalysts were reduced by hydrogen for 6 hours, raising the temperature to $360{ }^{\circ} \mathrm{C}$ at a rate of $2 \mathrm{~K} / \mathrm{min}$. Before being unloaded from the reactor, the catalyst was passivated with gaseous nitrogen containing $\sim 0.002 \mathrm{wt} . \%$ of oxygen.

Characterization of catalysts. The metal content on a carbon support was determined by X-ray spectral method on a VRA-30 fluorescence analyzer with a chromic anode of X-ray tube. The specific surface areas of the samples were determined by thermal nitrogen desorption using a Sorptomatic 1900 specific surface area analyzer.

The HRTEM analysis was carried out on a JEM-2010 high-resolution transmission electron microscope (Japan) with a grating resolution of $0.14 \mathrm{~nm}$ and an accelerating voltage $200 \mathrm{kV}$. The average particle diameter (at least 250 particles) was calculated using the following formula:

$$
d_{m}=\frac{\sum_{i}\left(x_{i} d_{i}\right)}{\sum_{i} x_{i}}, x_{i}-\text { number of particles with diameter } d_{i}
$$

Elemental analysis of samplesurface (EDX) was carried out with an EDAX DX-4 energy dispersive X-ray detector (Ametek Inc., USA). The analyzed surface area was $150-300 \mathrm{~nm}^{2}$.

FDEA hydrogenation. Hydrogenation was carried out in a glass reactor with a reflux condenser at $60{ }^{\circ} \mathrm{C}$. A catalyst (standard weight $0.2 \mathrm{~g}$ ) was loaded into the reactor, followed by pretreatment for $1 \mathrm{~h}$ in a stream of hydrogen at $200^{\circ} \mathrm{C}$. The initial reaction mixture was a FDEA solution $(0.24 \mathrm{ml})$ and a solvent $(20 \mathrm{ml})$. Hydrogen from the balloon was preliminarily passed through a column with a Ni-Cr catalyst for purification from oxygen impurities and through a column with a sorbent for purification from water impurities, and then fed into reactor. The reaction products were sampled and analyzed by GC/MSand GLC. 
Analysis of the reaction mixture. The condensed products were identified by VG-7070 GC/MS (30 mx $0.2 \mathrm{~mm}$ Silicone SE-30 column) and Agilent 5973N EI / PCI (30 mm x $0.25 \mathrm{~mm}$ HP-5ms column). Quantitative analysis of the reaction mixtures was carried out GLC on an LKhM-80 (NPO Agropribor) with a flame ionization detector and quartz packed column $2.0 \mathrm{~m} \times 2.0 \mathrm{~mm}$ filled with Chromosorb 101 sorbent modified with $5 \%$ FFAP and nitrogen as carrier gas.The chromatograms were processed using the Gepard software package.

\section{Results and discussion}

Influence of the catalyst nature on FDEA hydrogenation. Table 1 presents effect of the catalyst nature on the hydrogenation process. The FDEA hydrogenation gives tetrahydrofuran diethyl acetal (THFDEA, single product stable for 5-10 hours) fast and selectively on a palladium catalyst in hexadecane at $100{ }^{\circ} \mathrm{C}$ (Table 1). The palladium-rhenium catalyst is inactive in the process of FDEA hydrogenation: the substrate conversion in 10 hours does not exceed $50 \%$, and the yields of EFE and THFDEA do not exceed $5 \%$. Copper-ruthenium catalysts in oxidized and reduced forms are practically inactive at atmospheric pressure - the FDEA concentration practically does not change for 6 hours, and the yield of THFDEA, the main product, does not exceed 2-4 mol.\%.

The results obtained show that the dominant route in the processes with all studied catalysts is the FDEA ring hydrogenation with the THFDEA formation. EFE, the product of $\mathrm{C}-\mathrm{O}$ bonds hydrogenolysis in a ring substituent, is practically not formed. Based on the results obtained, a more detailed study of the process was carried out on the most active catalyst, palladium on Sibunit.

Influence of the FDEA concentration and the state of the palladium catalyst on the hydrogenation process. Fig. $2-4$ show the dependences of the FDEA conversion and the accumulation of products, THFDEA, EFE and FA on FDEA concentration and the state of the catalyst (initial and one cycle spent).

Table 1. Influence of the catalyst nature on the FDEA hydrogenation. Experimental conditions: $0.24 \mathrm{ml} \mathrm{FDEA,} 20$ $\mathrm{ml}$ tetrahydrofuran (THF), $0.1 \mathrm{~g}$ catalyst, $60^{\circ} \mathrm{C}, 1 \mathrm{~atm} \mathrm{H}_{2}$

\begin{tabular}{|c|c|c|c|c|}
\hline Catalyst & Time, h. & FDEA, mM & THFDEA, mM & EFE, mM \\
\hline \multirow{3}{*}{$6 \% \mathrm{Pd} / \mathrm{C}^{*}$} & 0 & 72,8 & 0 & 0 \\
\hline & 5.5 & 1,64 & 70,8 & 0 \\
\hline & 11 & 0,21 & 73,4 & 0 \\
\hline \multirow{4}{*}{$8 \% \mathrm{CuRu} / \mathrm{C}$} & 0 & 69,7 & 0 & 0 \\
\hline & 3,0 & 69,7 & 0,08 & 0 \\
\hline & 4,5 & 68,0 & 0,17 & 0,20 \\
\hline & 6,0 & 71,6 & 0 & 0 \\
\hline \multirow{3}{*}{$\begin{array}{c}8 \% \mathrm{CuRu} / \mathrm{C} \\
\text { (reduced) }\end{array}$} & 3,0 & 68,5 & 0,17 & 0 \\
\hline & 4,5 & 68,6 & 0,18 & 0 \\
\hline & 6,0 & 66,5 & 0,26 & 1,13 \\
\hline \multirow{2}{*}{$\begin{array}{c}1 \% \mathrm{Pd}+ \\
4 \% \mathrm{Re} / \mathrm{TiO}_{2}, 60^{\circ} \mathrm{C}\end{array}$} & 8 & 41,3 & 2,07 & 0,40 \\
\hline & 10 & 30,8 & 1,77 & 2,00 \\
\hline
\end{tabular}

*hexadecane, $100^{\circ} \mathrm{C}$. 

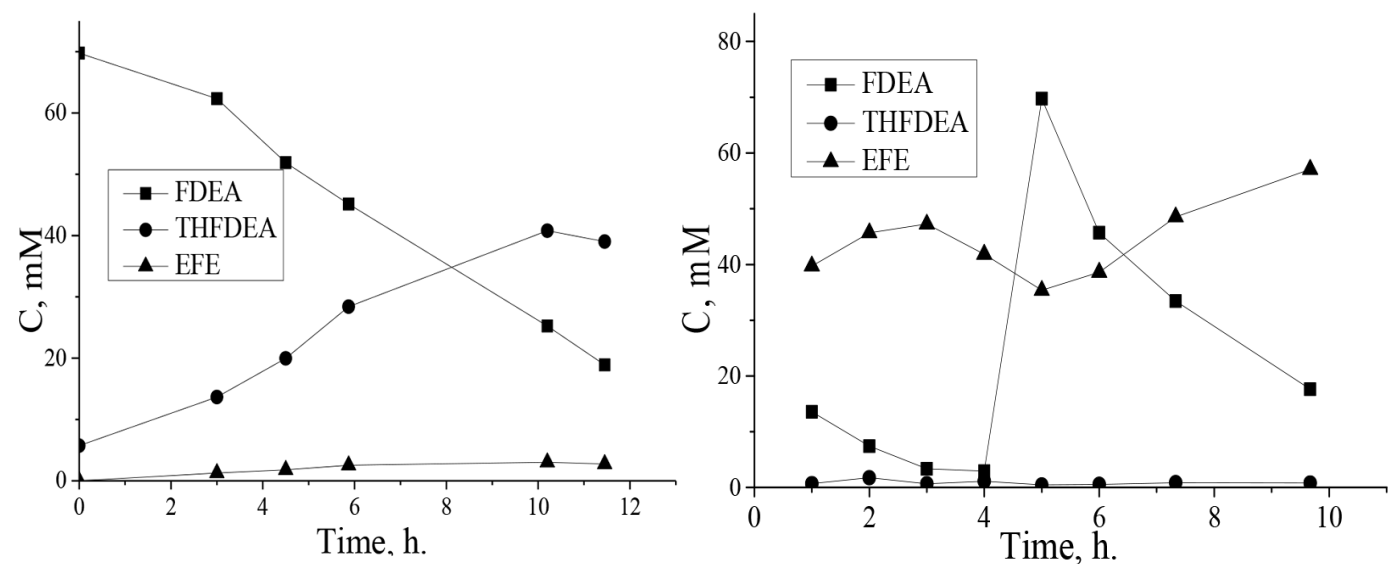

Fig. 2. Kinetic dependences of FDEA hydrogenation process on an initial $\mathrm{Pd} / \mathrm{C}$ catalyst (left) and one cycle spent (right).0.071 M FDEA in THF, $0.5 \%$ catalyst, $60{ }^{\circ} \mathrm{C}$, atmospheric pressure, hydrogen flow into the reactor
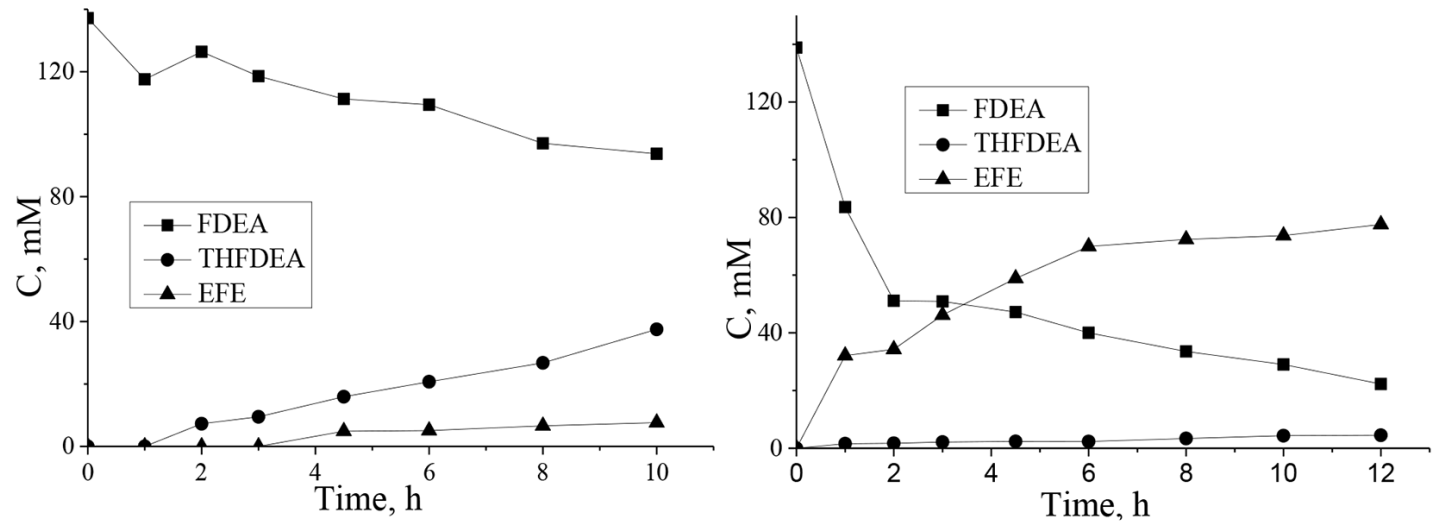

Fig. 3. Kinetic dependences of FDEA hydrogenation process on an initial Pd/C catalyst (left) and one cycle spent (right). 0.142 M FDEA in THF, other conditions see Fig. 2
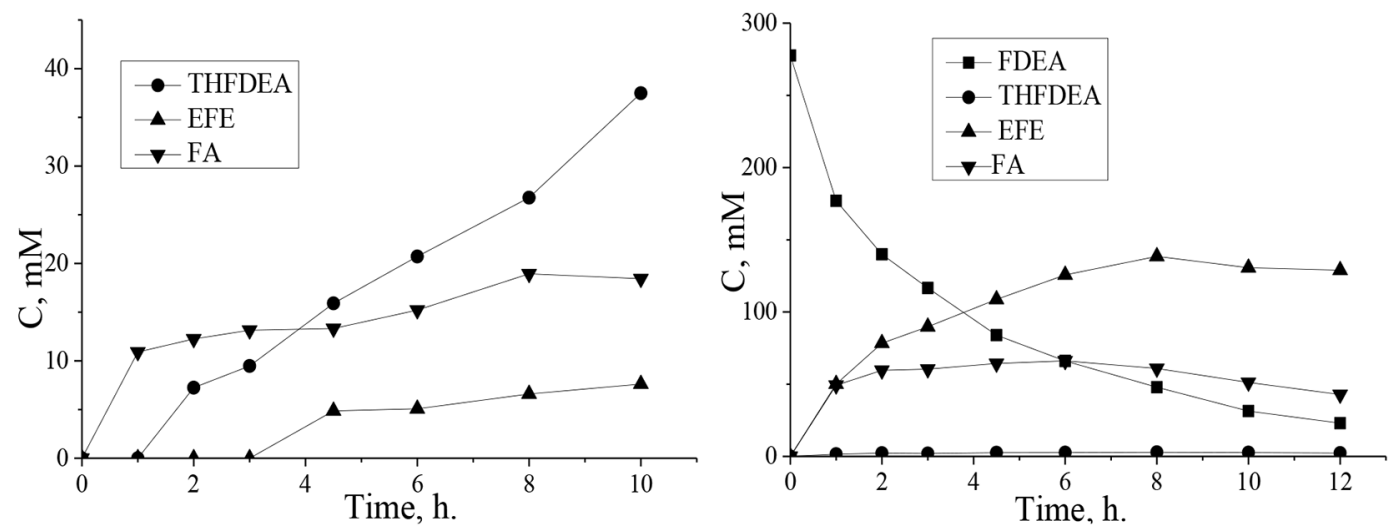

Fig. 4. Kinetic dependences of FDEA hydrogenation process on an initial Pd/C catalyst (left) and one cycle spent (right). 0.284 M FDEA in THF, other conditions see Fig. 2 
The most important regularities of hydrogenation are observed while going from the initial catalyst to the one cycle spent catalyst. The first, for all three concentrations, a tenfold or more increase in the hydrogenation rate is observed passing from the initialcatalystto the spent one. The second is the change of the process selectivity: the products of ring hydrogenation are obtained on an initial catalyst, and the products of the acetal substituent hydrogenolysis, primarily EFE, are formed on a one cycle spent catalyst. The EFE maximum yield exceeds 55 mol.\%, and the selectivity reaches $85 \%$ (Fig. 2). This selectivity is in good agreement with the best literature data [16].

The change of selectivity of heterogeneous catalytic processes during the catalyst deactivation is well known, and it is often caused by coking the active surface of the catalyst crystals. Usually such change of selectivity is accompanied by a decrease in the overall process rate [25].

The growth of catalyst activity during a processis quiet rare but known phenomenon. There are at least two possible mechanisms for increasing the rate of heterogeneous catalytic process with catalyst aging. The first consists in the destruction of catalyst particles, up to the dissolution of its active components and transition of process to homogeneous regime. The second is palladium migration from inner pores of catalyst grain to its external surface, and this can lead to an increase of liquidphase process rate, as the availability of the internal surface of the catalyst grain is strongly limited by low diffusion rates in a liquid phase [26].

As for the considered process, more specific explanation is possible for changing the selectivity and rate during the transition from initial catalyst to one spent a cycle. It was found that hydrogenation of double bonds of the ring with the formation of tetrahydrofurfuryl alcohol occurs mainly in the FAL hydrogenation on reduced forms of a palladium catalyst, while oxidized forms of palladium catalyze the hydrogenolysis of $\mathrm{C}-\mathrm{O}$ bonds of alcohol and carbonyl substituents with MF formation [27]. Probably, this effect takes place during the transition from initial (reduced form) to a spent catalyst (oxidized form) as a result of contact with air during reloads. This change of oxidation state of active metal can lead to changing the hydrogenation route $[6,27]$ and increasing the catalytic process rate.

\section{Conclusion}

The process of furfural diethyl acetal catalytic hydrogenation has been studied. On all studied catalysts (reduced forms of palladium, palladium-rhenium, and copper-ruthenium on Sibunit), tetrahydrofuran diethyl acetal is formed as the main product, i. e. the main route is a furan ring hydrogenation.

It was found that when the second hydrogenation cycle is carried out on a spent palladium catalyst, the reaction rate increases by an order of magnitude and ethyl furfuryl ether becomes the main product of the second hydrogenation cycle (yield and selectivity up to $55 \%$ and $85 \%$ respectively). This catalyst behavior is probably associated with the oxidation of active surface of palladium catalyst as a result of its contact with air when the catalyst and reagents are reloaded. Such a conclusion on the behavior of palladium catalysts in the processes of hydrogenation of furan derivatives (hydrogenation of furan ring on reduced forms and hydrogenolysis of $\mathrm{C}-\mathrm{O}$ bonds of substituents on the oxidized palladium) was made in $[6,27]$. 


\section{Acknowledgements}

This work was carried out within the framework of the budget project № 0287-2021-0017 for Institute of Chemistry and Chemical Technology SB RAS using the equipment of Krasnoyarsk Regional Research Equipment Centre of SB RAS.

\section{References}

1. Tarabanko V.E., ChernyakM.Yu., Kuznetsov B.N., Zakharova O. V. Investigation of the processes of acid-catalytic dehydration of carbohydrates in the presence of butanol at moderate temperatures. Khimiya rastitel'nogo syr'ya 2002. V. 2, P. 5-15. (In Russ.).

2. Tarabanko V.E., Smirnova M. A., Chernyak M. Yu., Kondrasenko A. A., Tarabanko N. V. The nature and mechanism of selectivity decrease of the acid-catalyzed fructose conversion with increasing the carbohydrate concentration. Journal of Siberian Federal University. Chemistry 2015. V. 8(1), P. 6-18.

3. Roman-Leshkov Y., Barrett C.J., Liu Z.Y., Dumesic J.A. Production of dimethylfuran for liquid fuels from biomass-derived carbohydrate. Nature 2007. V. 447, P. 982-986.

4. Alonso D.M., Bond J. Q., Dumesic J.A. Catalytic conversion of biomass to biofuels. Green Chemistry 2010. V. 12, P. 1493-1513.

5. Varfolomeev S.D., Moiseev I.I., Myasoedov B.F. Renewable energy sources. Chemical aspect. Vestnik RAS2009. V. 79(7), P. 595-604. (In Russ.).

6. Chen S., Wojcieszak R., Dumeignil F., Marceau E., Royer S., How catalysts and experimental conditions determine the selective hydroconversion of furfural and 5-hydroxymethylfurfural. Chemical Reviews 2018. V. 118(22), P. 11023-11117. DOI:10.1021/acs.chemrev.8600134.

7. Lange J.-P., Heide E., Buijtenen J., Price R. Furfural - a promising platform for lignocellulosic biofuels. ChemSusChem 2012. V. 5(1), P. 150-166. DOI: 10.1002/cssc.201100648.

8. Maksimov A.L., Nekhaev A.I., Ramazanov D.N. Ethers and acetals are promising petrochemical products from renew able raw materials (review). Neftekhimiya 2015. V. 55(1), P. 3-24.

9. Tarabanko V.E., Chernyak M. Yu., Morozov A.A., Kaigorodov K.L., Bezborodov Yu.N., Orlovskaya N.F., Nadeikin I. V. New high-octane components of gasoline from plant raw materials. Journal of Siberian Federal University. Chemistry2014. V. 7(1). P. 31-35. (In Russ.).

10. Tarabanko V.E., Chernyak M. Yu., Simakova I.L., Kaigorodov K.L., Bezborodov Yu.N., Orlovskaya N. F. Antiknock properties of furfural derivatives. Russian Journal of Applied Chemistry 2015. V. 88(11), P. 1778-1782. (In Russ.).

11. Wissell L, Tollens B. XXXIII. Ueber den furfur- oderfuralkohol und einige derivate desselben. Justus Liebigs Annalen der Chemie 1893. V. 272(3), P. 291-306.

12. Potapov V. M. Organikum. Practical works on organic chemistry. V. 2. Moscow: Mir, 1979. P. 64. (In Russ.).

13. Patil C.R., Rode C.R. Selective production of furanic ethers from lignocellulosic biomass over mesoporous Zr-incorporated SBA-15 catalyst. Chemistry Select 2018. V. 3, P. 12504-12511. DOI: 10.1002/slct.201801939.

14. Luijkx G.C.A., Huck N.P.M., Rantwijk F., Maat L, Bekkum H. Ether formation in the hydrogenolysis of hydroxymethylfurfural over palladium catalysts in alcoholic solution. Heterocycles 2009. V. 77(2), P. 1037-1044. DOI: 10.3987/COM-08-S(F)81. 
15. Antunes M.M., Lima S., Neves P., Magalhaes A. L., Fazio E., Fernandes A., Neri F., Silva C. M., Rocha M.S., Ribeiro M.F., Pillinger M., Urakawa A., Valente A. A.. One-pot conversion of furfural to useful bio-products in the presence of a $\mathrm{Sn}$, Al-containing zeolite beta catalyst prepared via postsynthesis routes. Journal of Catalysis 2015. V. 329, P. 522-537. DOI: 10.1016/j.jcat.2015.05.022.

16. Wang Y., Cui Q., Guan Y., Wu P. Facile synthesis of furfuryl ethyl ether in high yield via reductive etherification of furfural in ethanol over Pd/C under mild conditions. Green Chemistry 2018. V. 20(9), P. 2110-2117. DOI: 10.1039/C7GC03887A.

17. SimakovaI.L., Tarabanko V.E.,ChernyakM. Yu.,Kondrasenko A. A.,Simonov M.N. Catalytic hydrogenation of furfural in alcoholic media. Journal of Siberian Federal University. Chemistry 2015. V. 8(4), P. 481-489. (In Russ).

18. Dutta S., Mascal M. Novel pathways to 2,5-dimethylfuran via Biomass-derived 5-(chloromethyl)furfural. ChemSusChem 2014. V. 7(11), P. 3028-3030. DOI: 10.1002/cssc.201402702.

19. Simakova I.L., Tarabanko V.E., Morozov A.A., Chernyak M. Yu. Catalytic hydrogenation of 5-butoxymethylfurfural over copper-containing catalysts. South Siberian Scientific Bulletin 2014. V. 3(7), P. 37-42.

20. Simakova I.L., Morozov A. A., Tarabanko V.E., Chernyak M. Yu. Catalytic hydrogenation of 5-butoxymethylfurfural over palladium catalysts. Journal of Siberian Federal University. Chemistry 2014. V. 7(4), P. 536-545.

21. ChernyakM.Yu., Tarabanko V.E., Morozov A. A., Kondrasenko A. A. Preparative synthesis of furfural diethyl acetal through the direct interaction of the alcohol and aldehyde. Journal of Siberian Federal University. Chemistry 2016. V. 9(2), P. 146-151. DOI: 10.17516/1998-2836-20169-2-146-151.

22. Simakova O.A., Simonov P.A., Romanenko A.V., Simakova. I.L. Preparation of Pd/C catalysts via deposition of palladium hydroxide onto sibunit carbon and their application to partial hydrogenation of rapeseed oil. Reaction Kinetics and Catalysis Letters 2008. V. 95 (1), P. 3-12.

23. Simakova I.L., Prosvirin I. P., Kriventsov V. V., Parmon V. N. Influence of the synthesis conditions on the catalytic and physicochemical properties of $\mathrm{Pd} / \mathrm{C}$ in the reaction of reductive debenzylation. Journal of Siberian Federal University. Chemistry 2012. V. 5(3), P. 238-245. (In Russ).

24. Simonov M.N., Prosvirin I. P., Chetyrin I. A., Simakova I. L. Development of a cascade process for the conversion of pentanoic acid to n-nonane in the presence of palladium supported on zirconium oxide. Journal of Siberian Federal University. Chemistry 2013. V. 6(4), P. 331-343. (In Russ).

25. Zaitseva N.A., Molchanov V.V., Chesnokov V.V., Buyanov R. A., Zaikovskyi V.I. Effect of the nature of coke-forming species on the crystallographic characteristics and catalytic properties of metal-filamentous carbon catalysts in the selective hydrogenation of 1,3-butadiene. Kinetics and Catalysis 2003. V. 44(1), P. 129-134.

26. Ioffe I.I., Pismen L. M. Engineering chemistry of heterogeneous catalysis.L. Khimia, 1972. 466 p. (In Russ).

27. Iqbal S., Liu X., Aldosari O.F. Miedziak P.J., Edwards J.K., Brett, G.L., Akram A., King G. M., Davies T.E., Morgan D. J., Knight D. K., Hutchings G. J. Conversion of furfuryl alcohol into 2-methylfuran at room temperature using $\mathrm{Pd} / \mathrm{TiO}_{2}$ catalyst. Catalysis Scienceand Technologies 2014. V. 4(8), P. 2280-2286. DOI: 10.1039/c4cy00184b. 